\title{
三峡库区的入侵鱼类及库区蓄水对外来鱼类入侵的影响初探”
}

\author{
巴家文, 陈大庆 ${ }^{* *}$
}

(中国水产科学研究院长江水产研究所,农业部长江中上游渔业资源环境科学观测实验站,武汉 430223)

\begin{abstract}
摘 要: 三峡水库已于 2010 年 10 月完成 $175 \mathrm{~m}$ 的蓄水目标, 蓄水后三峡库区形成一个生态位严重空缺的人造湖泊生态 系统. 近年来, 库区及长江上游外来人侵鱼类呈增长态势, 已发现外来人侵鱼类 23 种, 且部分已处于种群数量暴发阶段. 水库蓄水初期营养盐输人增加和初级生产力的提高通常也利于广适性鱼类和外来种的生存, 对外来鱼类的人侵和种群 数量的扩散暴发产生一定的促进作用. 外来鱼类在生态位竞争上与土著鱼类相比处于明显优势地位, 可能将严重危害三 峡库区的渔业资源及其水域生态系统的安全. 因此,对于三峡库区的鱼类人侵及其所带来的相关效应等问题,应引起密 切关注和重视, 尽早建立三峡库区人侵鱼类的预警和防治体系, 严格评估人为引种活动, 深人研究外来鱼类得以成功人 侵的原因与机理.
\end{abstract}

关键词: 三峡库区;鱼类人侵;蓄水;监测; 入侵危害

\section{Invasive fishes in Three Gorges Reservoir area and preliminary study on effects of fish in- vasion owing to impoundment}

\section{BA Jiawen \& CHEN Daqing}

(Scientific Observing and Experimental Station of Fishery Resources and Environment in the Upper and Middle Reaches of the Yangtze River, Ministry of Agriculture, Yangtze River Fisheries Research Institute, Chinese Academy of Fishery Sciences, Wuhan 430223 , P. R. China)

\begin{abstract}
Three Gorges Reservoir has become a man-made lake ecosystem where there are a lot of ecological niches left vacant or unused. Alien species appear to be successful invaders to fill these empty ecological niches. In recent years, a total of 23 invasive fish species have been found in this reservoir and the upper reaches of Yangtze River, some of which are in the stage of their population outbreak. The main reasons for this are increased nutrient inputs and thus high primary productivity in the initial time of impoundment. They facilitated the invasion of exotic fish species that have the adaptability to a wide range of environmental conditions. With a competitive advantage over indigenous fishes, invasive alien species can replace them. This may be seriously harmful to the fishery resources and aquatic ecological systems in Three Gorges Reservoir. Evidently, more attention should be paid to affects and other related issues caused by the invasive alien fish. The following measures can be urgently taken: the establishment of the early warning and prevention systems of invasive alien fish species, the assessment on the potential affects of the introduction of alien cultured fishes, and thorough investigations of mechanisms of exotic fish fishes as the successful invaders adapted for the reservoir environmental conditions.
\end{abstract}

Keywords: Three Gorges Reservoir area; fish invasion; impoundment; monitor; invasive harm

生物人侵是全球生态环境研究热点之一, 随着经济全球化进程的加快,外来物种的人侵速度也得到飞 速提升，所造成的危害也越来越大. 2003 年我国环境保护部的调查发现,外来人侵物种当年造成的经济损 失高达 1198.76 亿元, 占中国 GDP 的 $1.36 \%{ }^{[1]}$. 我国目前在昆虫和植物人侵方面的研究较多, 对于水生生 物特别是鱼类的人侵研究还相对较少, 因为鱼类人侵过程较为隐蔽, 在其人侵的早期阶段难以察觉, 等到被

* 公益性行业(农业)科研专项经费项目 (200903048-01) 资助. 2011-10-14 收稿;2011-12-05 收修改稿. 巴家文, 男,1984 年生,硕士;E-mail: bajw@yfi. ac. cn.

** 通信作者;E-mail: chdq@ yfi. ac. cn. 
发现时,基本都已建立起稳定的繁殖种群,甚至已处于种群数量暴发阶段.

2006 年我国大陆引进的国外和部分国内不同区域的外来水生经济鱼类共 89 种, 仅从国外引进的鱼类 就达 65 种以上, 其中还不包括作为观赏鱼引进的大量外来鱼种 ${ }^{[2]}$. 外来鱼类的人侵已在我国许多水系造成 严重危害, 如云贵高原上的湖泊无论面积大小都不同程度地受到生物人侵的影响, 成为土著鱼类物种多样 性显著降低以及种群数量急剧下降的主要因素 ${ }^{[3]}$. 云南沪沽湖分布的 3 种裂腹鱼类由于引人的麦穗鱼等小 型鱼类吞食其鱼卵而造成绝迹 ${ }^{[4-5]}$. 陈锋等在 2004-2006 年对西藏拉萨河鱼类的采样调查中发现 8 种外来 鱼类, 占总渔获物种类的 $42.5 \%$, 甚至有些生境已难受土著鱼类的踪迹 ${ }^{[6]}$. 在雅鲁藏布江中游也发现 9 种外 来鱼类, 占渔获物种类的 $39.13 \%$, 且已形成定殖种群 ${ }^{[7]}$. 新疆乌伦古湖土著鱼类的生态位大部分已被外来 鱼类所占据, 以前最重要的土著经济鱼类河鲈正濒临灭绝 ${ }^{[8]}$.

三峡库区位于长江上游的下段,东起湖北省宜昌市,西至重庆市. 库区由丘陵、中低山和峡谷组成, 东段 为深嵌于巫山山脉中的三峡峡谷,长约 $160 \mathrm{~km}$, 西段为四川盆地东部的低山丘陵区, 长约 $450 \mathrm{~km}$. 三峡工程 蓄水到 $175 \mathrm{~m}$ 时, 形成 1000 余平方千米水域面积的库区, 上起于重庆市巴南区, 下止于湖北省宜昌市, 库区 范围涉及 19 个县市, 面积 $5.4 \times 10^{4} \mathrm{~km}^{2}$. 三峡地区位于四川盆地与长江中下游平原过渡带, 其上接青藏高 原,下连江汉平原. 三峡的形成先后经历喜马拉雅造山运动和巫山隆起运动, 在切割武陵山系的过程中, 形 成复杂的河流水域环境 ${ }^{[9]}$. 适应于这一环境,鱼类区系组成成分复杂多样, 具有长江上游和江淮平原鱼类组 成类型交错的特点 ${ }^{[10]}$. 2005-2006 年对三峡库区长江干流及主要支流的鱼类资源调查共发现鱼类 108 种, 其中特有鱼类 17 种 ${ }^{[11]}$.

三峡库区是我国重要的淡水经济鱼类和特有鱼类资源库,这些鱼类具有重要的科学价值、经济价值和 生物多样性价值. 近年来, 三峡库区沿岸各县市引人数十种外来养殖物种, 如胡子鲇 (Claris fuscus)、虹䲡 (Oncorhynchus mykiss)、尼罗罗非鱼 (Oreochromis niloticus)、大口黑鲈( Micropterus salmoides)、短盖巨脂鲤 (Colossoma brachypomum)、匙吻鲟 ( Polyodon spathula)、俄罗斯鲟 (Acipenser gueldenstaedti)、史氏鲟 (Acipenser schrencki) 、斑点叉尾鮰 (Ictalurus punctatus) 等. 太湖新银鱼 (Neosalanx taihuensis) 也已在库区各江段渔获物中 频频出现, 且捕捞数量逐年增多. 这些物种的引进缺乏统一的规划和管理及必要的生态风险评估,而渔业养 殖场也缺乏必要的物种隔离设施及防逃手段,极易造成外来物种的逃逸. 已有研究表明,外来物种的引进很 可能造成生态灾难, 如滇池引人银鱼等已导致当地特有鱼类和经济资源枯竭, 云南许多湖泊也因受外来鱼 类人侵导致土著鱼类数量锐减, 生态系统濒临崩溃 ${ }^{[12]}$. 水库在蓄水初期, 由于水体营养动力学的改变, 通常 有利于广适性鱼类和外来鱼类的生存, 而对特有鱼类和土著鱼类造成威胁 ${ }^{[13-14]}$.三峡水库已于 2010 年 10 月 完成 $175 \mathrm{~m}$ 蓄水目标后, 区域性的环境变化使得库区形成一个生态位严重空缺的湖泊生态系统,外来鱼类侵 人库区后, 在争夺食物饵料和生存空间上相对土著鱼类都明显处于优势地位, 可能将严重危害到三峡库区 的渔业资源及其水域生态系统的安全. 因此,对于三峡库区的鱼类人侵及其所带来的相关效应等问题,应引 起我们的密切关注和重视.

\section{1 三峡库区的入侵鱼类}

对三峡库区人侵鱼类的调查及相关历史文献的查阅发现, 目前三峡库区共有人侵鱼类 23 种,其中来自 美洲水系的有 10 种, 欧洲 2 种, 非洲 2 种,其余都是从我国其他水系侵人 (表 1).2005-2007 年间对三峡库 区渔业资源进行调查发现,2005 年三峡库区内发现丁鰹、斑点叉尾鮰、黑鮰、大口黑鲈、大银鱼、团头鲂 6 种 往年未采集到的人侵鱼种, 被认为可能是养殖逃逸的个体 ${ }^{[11]} .2006$ 年春季和秋季, 在长江上游的攀枝花、宜 宾、合江、木洞、涪陵、万州以及宜昌江段进行了 2 次野外调查, 共发现 6 种外来人侵鱼类, 分别为史氏鲟、丁 鱥、斑点叉尾鮰、黑鮰、大口黑鲇和罗非鱼; 其中, 攀枝花江段的史氏鲟为首次发现 ${ }^{[15]} .2007$ 年, 在金沙江下 游攀枝花、宜宾江段, 长江上游合江、木洞、万州以及长江中游宜昌江段也调查到外来人侵鱼类 6 种, 分别为 斑点叉尾鮰、黑鮰、大口黑鲇、罗非鱼、食蚊鱼和短盖巨脂鲤 ${ }^{[16]}$. 
表 1 三峡库区人侵鱼类名录及人侵时间

Tab. 1 Catalogue of invasive fish in Three Gorges Reservoir and invasive time

\begin{tabular}{|c|c|c|}
\hline 人侵鱼类 & 原产地 & 人侵时间 \\
\hline 斑点叉尾鮰( Ictalurus punctatus) & 美国密西西比河 & $1983 *[17]$ \\
\hline 丁鱥( Tinca tinca) & 欧洲水系、新疆、内蒙古水系 & $1998 *[18]$ \\
\hline 俄罗斯鲟( Acipenser gueldenstaedti) & 里海、亚速海和黑海 & $1993 *[18]$ \\
\hline 匙吻鲟 (Polyodon spathula) & 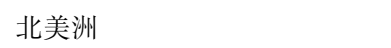 & $1990 *[17]$ \\
\hline 史氏鲟( Acipenser schrencki) & 黑龙江、乌苏里江、松花江 & $2006^{[15]}$ \\
\hline 下口鲇 (Hypostomus plecostomus) & 拉丁美洲 & $1999^{[19]}$ \\
\hline 白肌银鱼 (Leucosoma chinensis) & 我国东海、南海 & \\
\hline 太湖新银鱼 (Neosalanx taihuensis) & 长江中、下游湖泊 & \\
\hline 前领间银鱼 (Hemisalanx prognathus) & 长江中下游鄱阳湖和太湖水域 & \\
\hline 大银鱼 (Protosalanx haylocranius) & 长江中、下游及其所属湖泊 & \\
\hline 短吻间银鱼 (Hemisalanx brachyrostralis) & 长江中下游及沿江大中型湖泊 & \\
\hline 胡子鲇 (Claris fuscus) & 长江流域以南各水体 & $1981 *[19]$ \\
\hline 虹鳟( Oncorhynchus mykiss) & 北美洲 & $1959 *[17]$ \\
\hline 尼罗罗非鱼( Oreochromis niloticus) & 非洲 & $1978 *[19]$ \\
\hline 莫桑比克罗非鱼 (Oreochromis mossambicus) & 非洲 & $1957 *[19]$ \\
\hline 大口黑鲈 (Micropterus salmoides) & 美国密西西比河水系 & $1983 *[19]$ \\
\hline 短盖巨脂鲤 (Colossoma brachypomum) & 南美亚马逊河 & $1985^{*[17]}$ \\
\hline 麦穗鱼 (Pseudorasbora parva) & 长江中下游湖泊 & $1963 *[19]$ \\
\hline 食人鱼 (Pygocentrus nattereri) & 南美洲亚马逊河流域 & $1982 *[20]$ \\
\hline 食蚊鱼( Gambusia affinis) & 美国东南部、墨西哥及古巴 & $1924 *[2]$ \\
\hline 雀鳝( Lepisosteus oculatus) & 北美洲五大湖水域 & $1990 *[17]$ \\
\hline 团头鲂 (Megalobrama amblycephala) & 长江中游湖泊 & $2006^{[11]}$ \\
\hline 黑鮰 (Ameiurus melas) & 北美洲 & $2006^{[11]}$ \\
\hline
\end{tabular}

*首次报道人侵中国时间.

\section{2 三峡库区的蓄水过程与外来鱼类入侵}

长江三峡水利枢纽工程的建设分三期, 随着工程的进展, 三峡库区水位的变化可划分为四个阶段 ${ }^{[21]}$ : （1）1997 年 11 月,三峡大坝首次截流,库区蓄水水位约提升了 $10 \mathrm{~m}$; (2) 2002 年底至 2003 年 6 月,在导流 明渠截流后, 大坝将逐步蓄水, 长江三峡水位将由 $66 \mathrm{~m}$ 提高到 $135 \mathrm{~m}$, 尾水至重庆万县市境内, 水面变得平 缓; (3) 2006 年 9 月,三峡蓄水水位将提高到约 $150 \mathrm{~m}$, 水面及长江三峡景点变化不大; (4) 2009 年 10 月, 三 峡工程全面竣工, 蓄水水位达 $158 \mathrm{~m}, 2010$ 年 10 月最终达到最高目标蓄水水位 $175 \mathrm{~m}$, 坝前水位提高近 $110 \mathrm{~m}$,水位每年有近 $30 \mathrm{~m}$ 的升降变化.

三峡水库蓄水后, 库区水域水体加深、水流减缓, 形成了一个生态位严重空缺的人造湖泊生态系统, 其 营养物质远未得到充分利用 ${ }^{[3]}$. 蓄水后水流减缓, 水体透明度增大, 有机物和营养盐类增加, 有利于浮游生 物的生长和繁殖, 其种类和数量都显著增加 ${ }^{[22]}$. 水库在蓄水初期阶段由于水体营养动力学的改变, 通常也利 于广适性鱼类和外来种的生存, 而威胁特有种和土著鱼类的生存 ${ }^{[13-14]}$. 水库蓄水初期营养盐输人增加和初 级生产力提高, 为库区渔业发展提供重要的营养条件 ${ }^{[23]}$. 三峡水库 2003 年开始蓄水后, 随着库区水体水文 生态与水动力学特征、生境结构和水体生产力等的改变, 鱼类群落亦随之演替 ${ }^{[24]}$. 通过对三峡库区干支流的 调查分析, 发现蓄水后库区水体浮游植物数量较蓄水前有明显增长, 特别是坝前和支流河口及洄水段的浮 游植物数量增加明显 ${ }^{[25]}$. 库区内初级生产力的提高导致其饵料资源量增加, 也为外来人侵物种的种群暴发 提供了饵料基础. 如三峡水库蓄水至 $135 \mathrm{~m}$ 之前, 库区长江江段虽有太湖新银鱼的记录, 但并没有作为渔业 对象并形成一定的渔产量; 蓄水至 $135 \mathrm{~m}$ 以后, 太湖新银鱼种群数量迅速上升, 资源显著增加, 其种群暴发已 成为近期库区鱼类群落演替的显著特点之一, 2006 年以来已经成为库区渔业重要的商业捕捞对象 ${ }^{[26]}$. 


\section{3 三峡库区入侵鱼类可能造成的危害}

随着人类活动的愈加频繁, 外来物种人侵风险也越来越大, 外来鱼类物种的引人在带来可观经济效益 的同时可能也会给土著物种和生态系统造成巨大的危害. 在争夺食物饵料和生存空间方面, 人侵鱼类相对 土著鱼类明显处于优势 ${ }^{[27]}$. 外来人侵鱼类在与土著鱼类进行生态位的竞争中胜出, 种群密度大大提高, 并成 为优势种群, 土著鱼类明显处于劣势, 甚至濒临灭绝 ${ }^{[28]}$. 如太湖新银鱼被引人到云南高原湖泊形成优势种群 后,造成了当地一些土著鱼类的资源下降, 甚至灭绝 ${ }^{[12]}$.

人侵鱼类会吞食土著鱼类的鱼卵,造成以砾石为产卵和活动场所的土著鱼类数量急剧下降,一些物种甚 至濒临灭绝 ${ }^{[19]}$. 在长江上游的四川、重庆等地的天然水体中发现的下口鲶, 其繁殖力非常强, 每次产卵300 500 粒, 孵化率很高. 此种类不仅摄食藻类及其它饵料生物, 也大量吞食土著鱼类的卵, 从而严重威胁到土著 鱼类及水域生态系统. 根据长江三峡工程生态与环境监测系统的报告, 在三峡库区已经发现丁鱥、玟点叉尾 鮰、黑鮰、大口黑鲇、大银鱼等外来鱼类, 部分物种已经在库区大量繁殖, 种群数量急剧增长, 对库区鱼类群 落乃至渔业生态系统都造成严重影响 ${ }^{[29]}$.

外来入侵鱼类还可能与库区土著鱼类杂交, 导致长江上游土著鱼类种质被污染、种质资源退化甚至丧 失. 如云南省的星云湖曾因外来鲤鱼的人侵导致国家 II 级保护动物纯种大头鲤的灭绝, 目前湖中现生的鲤 鱼多为大头鲤和原产黑龙江的鲤鱼、元江的华南鲤、锦鲤、欧洲的鲤鱼等多种鲤鱼的杂交后代 ${ }^{[30]}$.

\section{4 三峡库区鱼类入侵预警和防治}

\section{1 严控人为引种和传播}

三峡库区是中国重要的淡水鱼类资源库, 分布有许多长江上游特有鱼类物种, 如岩原鲤、齐口裂腹鱼、 圆筒吻鮈、圆口铜鱼和异鳔鳅鮀等 ${ }^{[11]}$. 因此, 当库区引进外来物种时, 应提前对引进物种进行生态风险评估. 库区长江干流周边养殖场内和支流的网箱、围栏养殖水域, 如开县的小江河流域、巫山的大宁河流域, 巴东 的神龙溪流域等, 也应当建造物种隔离及防逃设施, 防止外来鱼类的逃逸. 外来鱼类的引进很有可能导致当 地特有鱼类资源枯竭,造成生态灾难, 因此在库区引进和养殖外来物种,应加强管理和风险评估.

\section{2 进行预警和监测}

外来鱼类在人侵过程不易发现,在人侵过程的早期阶段也很难被察觉,等到被发现时基本都已建立起 稳定的繁殖种群, 甚至已处于种群数量暴发阶段. 因此有必要加强对三峡库区外来人侵鱼类的预警和监测 工作, 通过设置固定监测站点 (如剓归、万州和巴南等) 和监测区域 (如坝前水域和库尾水域), 适时开展流 动监测,动态监测入侵鱼类种群变化及危害程度, 建立三峡库区人侵鱼类的预警和防治体系.

\section{3 加强土著鱼类保护}

三峡库区稳定性蓄水后, 库区成为生态位空缺的人工湖泊生态系统, 水体营养物质得不到充分利用. 针 对这一情形, 可以增殖放流一些土著鱼类, 如鲢、鳙、草鱼、鲤、鲫、鳊、鲂、鲖类等, 以及一些名特种类如黄颡 鱼、长吻鯔、鳜、鲌类等. 这些鱼类不仅具有较高的经济价值, 还能增加渔业捕捞产量, 更能缓解三峡库区的 富营养化问题, 净化库区水质. 放流的土著鱼类也可以很好地填补三峡库区生态位的空缺, 在一定程度上能 够降低外来鱼类的人侵风险.

\section{5 结论与展望}

近年来,在三峡库区渔业资源调查及监测过程中发现,外来入侵鱼类种类数量明显上升,多种人侵鱼类 种群数量急剧增长, 这可能将对三峡库区土著鱼类造成巨大的危害. 此前, 我国云贵高原湖泊因外来种的引 人致使土著鱼类物种多样性的丧失. 这种局面将极有可能在三峡库区重演, 因此三峡库区的外来人侵鱼类 应引起特别重视. 此外, 三峡库区蓄水水位提升以后, 库区水域水体加深、水流减缓, 形成一个生态位严重空 缺的湖泊,其营养物质远没有得到充分利用. 这也为外来鱼类人侵库区提供了非常有利的条件,对外来鱼类 的人侵和种群暴发产生了一定的促进作用. 因此, 我们呼吁应加强对三峡库区外来人侵鱼类的调查和研究 工作,设置固定监测站点和区域,动态监测人侵鱼类的种类及危害程度,建立起三峡库区人侵鱼类的预警和 
防治体系,严格评估在三峡库区的人为引种活动, 深人研究外来鱼类得以成功人侵的原因与机理. 致谢: 感谢中国水产科学研究院长江水产研究所刘绍平研究员、段辛斌副研究员、邓华堂和田辉伍博士给予 的宝贵建议和帮助, 在此谨致谢忱!

\section{6 参考文献}

[ 1 ] 徐海根, 强 胜. 中国外来人侵物种编目. 北京: 中国环境科学出版社, 2004.

[2 ] 王亚民, 曹文宣. 中国水生外来人侵物种对策研究. 农业环境科学学报, 2006, 25(1) : 7-13.

[ 3 ] 路瑞锁, 宋豫秦. 云贵高原湖泊的生物人侵原因探讨. 自然生态保护, 2003, 8: 35-37.

[ 4 ] 张国华, 曹文宣. 湖泊放养渔业对我国湖泊生态系统的影响. 水生生物学报, 1997, 21(3): 271-280.

[ 5 ] 陈银瑞, 杨君兴, 李再云. 云南鱼类多样性和面临的危机. 生物多样性, 1998, 6(4) : 272-277.

[6] 陈 锋, 陈毅峰. 拉萨河鱼类调查及保护. 水生生物学报, 2010, 34(2) : 278-285.

[7] 杨汉运, 黄道明, 谢 山等. 雅鲁藏布江中游渔业资源现状研究. 水生态学杂志, 2010, 3(6) : 120-126.

[ 8 ] 唐富江, 姜作发, 阿达可白克. 可尔江等. 新疆乌伦古湖河鲈二十年来种群生长变化及原因. 湖泊科学, 2009, 21(1) : 117-122.

[9] 杨达源. 长江三峡的起源与演变. 南京大学学报, 1988, 4(3) : 466-472.

[10］杨干荣. 湖北鱼类志. 武汉: 湖北科学技术出版社, 1987.

[11］吴 强, 段辛斌, 徐树英等. 长江三峡库区蓄水后鱼类资源现状. 淡水渔业, 2007, 37(2): 70-75.

[12] 熊飞, 李文朝, 潘继征等. 云南抚仙湖鱼类资源现状与变化. 湖泊科学, 2006, 18(3) : 305-311.

[13] Baxter RM. Environmental effects of dams and impoundments. Annual Review of Ecology and Systematics, 1977, 8: 255 283.

[14] Martinez PJ, Chart TE, Trammell MA et al. Fish species composition before and after construction of a main stem reservoir on the White River, Colorado. Environmental Biology of Fishes, 1994, 40: 227-239.

[15］ 2007 年长江三峡工程生态与环境监测公报. http://www. tgenviron. org.

[16］ 2008 年长江三峡工程生态与环境监测公报. http://www. tgenviron. org.

[17] 楼允东. 我国鱼类引种研究的现状与对策. 水产学报, 2000, 24(2): 185-192.

[18］李家乐, 董志国, 李应森等. 中国外来水生动植物. 上海：上海科学技术出版社, 2007.

[19] 李振宇, 解 炎. 中国外来人侵种. 北京: 中国林业出版社, 2002.

[20］罗建仁. 警惕“食人鱼”等外来物种人侵. 广东水族, 2003, 3:65.

[21] http://www. ctgpc. com. cn.

[22] 李文祥, 陈永柏, 刘家寿等. 三峡水库渔业发展对策探讨. 人民长江, 2008, 39(2) : 5-7.

[23] Fernando CH, Gurgel JJS, Moyou NAG. A global view of reservoir fisheries. International Review of Hydrobiology, 1998, 83( special issue) : $31-42$.

[24] 胡征宇, 蔡庆华. 三峡水库蓄水前后水生态系统动态的初步研究. 水生生物学报, 2006, 30 (1) : 1-6.

[25] 张 远, 郑丙辉, 刘鸿亮. 三峡水库蓄水后的浮游植物特征变化及影响因素. 长江流域资源与环境, 2006, 15 (2) : 254-258.

[26] 龚望宝, 吴 朗, 程 飞等. 三峡水库太湖新银鱼春季和秋季繁殖群体的繁殖生物学特征比较. 水生生物学报, $2010,34(5)$ : 1065-1068.

[27] Kolar CS, Lodge DM. Ecological predictions and risk assessment for alien fishes in North America. Science, 2002, 298 : 1233-1236.

[28 ] Clavero M, García-Berthou E. Invasive species are a leading cause of animal extinctions. Trends in Ecology and Evolution, $2005,20: 110$.

[29] http://www. tgenviron. org.

[30] Yang B, Chen XY, Yang JX. Non-native carp of the genus Cyprinus in Lake Xingyun, China, as revealed by morphology and mitochondrial DNA analysis. Biological Invasions, 2011, 13: 105-114. 